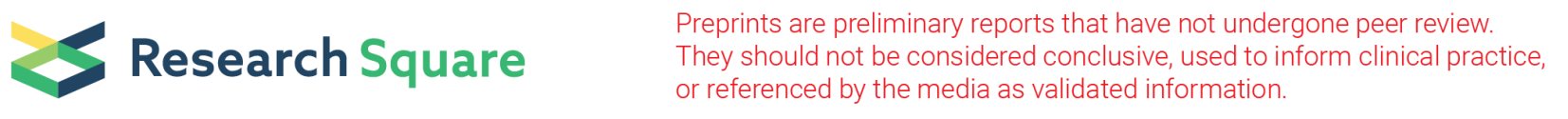

\title{
Practices And Challenges of Cultural Heritage Conservation In Historical And Religious Heritage Sites: Evidence From North Shewa Zone, Amhara Region
}

Habtamu Mekonnen

Debre Berhan University

Zemenu Bires

Debre Berhan University

Kassegn Berhanu ( $\nabla$ kassegnberhanu@gmail.com )

Debre Berhan University https://orcid.org/0000-0001-9981-5901

\section{Research Article}

Keywords: Cultural Heritage, Conservation, Practices, Challenges, Ethiopia

Posted Date: January 28th, 2022

DOI: https://doi.org/10.21203/rs.3.rs-1194895/v1

License: (-) (1) This work is licensed under a Creative Commons Attribution 4.0 International License. Read Full License 


\section{Abstract}

Cultural heritage are precious resources that showed the past human legacy, depicts present and future way of life as well as cultural values of a society, and it enhances solidarity and social integration of communities. However, due to natural catastrophes and anthropogenic factors, the sustainability of cultural heritage is questionable and requires scientific investigations to uncover the major problems affecting the continual of heritage attractions so that the panacea for this can be devised. Therefore, this study is designed to investigate the practices and challenges of cultural heritage conservations in North Shoa Zone, Central Ethiopia. Methodologically, the research employed a mixed research approach and cross-sectional descriptive and explanatory research design. While systematic random sampling technique is applied to select samples from local communities, purposive sampling was designed to choose interviewees. The target population of the study encompasses local communities, government authorities, and culture and tourism office experts of North Shoa Zone and respective districts. The actual and valid sample size of the study is 208. The findings of the study revealed that the cultural heritages are not safeguarded from damaging activities indicating a poor status of conservation. The major conclusion sketched from the study is the principal factors affecting heritage conservation are lack of proper management, monitoring and evaluation, lack of funds and stakeholder involvement, urbanization, settlement programs and agricultural practice, poor government concern and professional commitment, poor attitude towards cultural heritage and lack of community concern, vandalism and illicit trafficking, low promotions of cultural heritage, and natural catastrophes like invasive intervention, climate change (humidity and frost, excessive rainfall and flood, heat from the sun). The study implied that the sustainability of cultural heritage is endanger unless conservation practice is supported by conservation guidelines, heritage site management plans and research outputs, stakeholders' integration, and community involvement. Most importantly, the study recommends the integration of heritage conservation and sustainable development, and the promotion of conservation is a way of achieving economic and social sustainability.

\section{Introduction}

Heritage is our legacy from the past, what we live with today, and what we pass on to future generations. Our cultural and natural heritages are both irreplaceable sources of life and inspiration. They are our touchstones, our points of reference, our identity [1]. Cultural heritage is the legacy of physical artifacts, cultural property, and intangible attributes of a group or society that are inherited from past generations maintained in the present, and bestowed for the benefit of future generations [2].

According to UNESCO (1972: Article 1), Cultural heritages include monuments: architectural works, works of monumental sculpture and painting, elements or structures of an archaeological nature, inscriptions, cave dwellings and combinations of features; groups of buildings: groups of separate or connected buildings which, because of their architecture, their homogeneity or their place in the landscape; and sites: works of man or the combined works of nature and man, and areas including archaeological sites which are of outstanding universal value from the historical, aesthetic, ethnological or anthropological point of view [3].

Thus, cultural heritage is more than the monuments and objects that have been preserved over time. The cultural heritage of humanity also includes the living expressions and traditions that countless communities and groups receive from their ancestors and pass on to their descendants. Cultural heritage provides communities, groups, and individuals with a sense of identity and continuity, helping them to understand their world and giving meaning to their lives and their way of living together [3]. Proclamation no 209/2000 (article 3) classifies cultural heritage properties into tangible and intangible.

In the context of the cultures of the peoples of the various nations, nationalities, and peoples of Ethiopia, this definition could be used to incorporate their varied social, economic, political, administrative, moral, religious, and psychological conditions [4]. Ethiopia is a great country with its fabulous 3000 years history [5], a population of about 114 million people endowed with astonishingly rich linguistic and cultural diversity with more than 80 living languages and 200 dialects, spoken by as many ethnolinguistic communities [6].

In this era of globalization, there is a growing fear that cultures around the world will become more uniform, leading to a decrease in cultural diversity. To counter this potential homogeneity, strategies have been developed to preserve those cultures whose very existence could be threatened. Living cultures are highly susceptible to becoming extinct $[7,8]$. At present, the surge of interest in culture is creating new possibilities for safeguarding cultural heritage as a major component in building a sustainable cultural vision for the world [9]. In the context of UNESCO's activities, the value of cultural heritage and the importance and necessity of safeguarding 
it is now universally recognized. The UNESCO Convention for the Safeguarding of Cultural Heritage of 2003 refers to its preamble to "the universal will and the common concern to safeguard cultural heritage" [1].

Conservation of cultural heritage can be defined as all measures and actions aimed at safeguarding cultural heritage while ensuring its accessibility to present and future generations. Conservation embraces preventive conservation, remedial conservation, and restoration. All measures and actions should respect the significance and physical properties of the cultural heritage item [10].

In the case of Ethiopia, the Authorities for Research and Conservation of Cultural Heritage (ARCCH) within the Ministry of Culture and Tourism of Ethiopia and UNESCO Addis Ababa Office established a joint work plan (2006-2007) concerning inventorying cultural heritage in the country [5]. The main institutions of the country at the federal level, the Authorities for Research and Conservation of Cultural Heritage (ARCCH), within the Ministry of Culture and Tourism has a mandate for identifying and safeguarding both tangible and intangible cultural heritage. Both the 1995 Constitution and the 1997 Cultural Policy of Ethiopia refers to equal recognition of and respect for all Ethiopian languages, heritage, history, handicraft, fine arts, oral literature, traditional lore, beliefs, and other cultural features. These documents also mention the need to safeguard the cultural heritage of Ethiopia to ensure its transmission to future generations. Following the ratification of the 2003 Convention for the Safeguarding of the Cultural Heritage, the ARCCH designed a strategy for 2008-2010 on the identification, safeguarding, and promotion of cultural heritage through a national inventory-making exercise.

North Shoa has religious attractions (old churches, monasteries, holly springs) and historical sites such as Menz, Tegulet, Debre Birhan, Sela Dingay, Ankober, Liche, and Angolela which were Administrative Center or seats of Government for the Kings of Shewa and Ethiopia from the reign of Amde Tsion (1314-1344) and Zera Yakob (1434-1468) up to Emperor Menelik II (1865-1913. Most importantly, North Shoa is rich with religious sites (Tsadikanie Mariam, Kukyelesh Mariam, Abune Melike Tsedik, Zebir Gabriel, Seminesh Kidane Mihiret) which are famous for their annual religious ceremonies (Feast Day), Holy water that cure diseases and cleanse sins. Important traditional games such as Hockey and horse racing or Horse galloping are practiced Along with Feast Days.

However, despite the presence of plenty of tourism resources in Ethiopia in general and North Shoa Zone in particular, the sustainability of cultural heritage is in question and the contributions of the tourism sector for the locality are very low due to various impacts such as developments near or on heritage sites, absence of demarked buffer zones, lack of awareness or ignorance, theft and looting, embezzlement, inappropriate conservation practices, and natural damage/ deteriorations to mention few among many. The most widely known problems of cultural heritage include robbery digs at archaeological sites, the looting or destruction of cultural sites, and the theft of works of art from churches and museums all over the world [11]. Furthermore, to the best of our knowledge, there is no research conducted on practices, challenges, and impacts of cultural heritage conservations in the North Showa Zone. Hence, to address this research gap, the need to research challenges, impacts, and practices of cultural heritage conservation is one of the top priorities.

\section{Literature Review}

\subsection{Issues of Cultural Heritage}

\subsubsection{Cultural Ownership, Rights, Politics and Representation}

When the homogenization and standardization of heritage occur, the politics of cultural identity emerges as a critical issue. This is particularly true since heritage is not just a matter of the past, but very much a conduit for constructing the future [12]. In other words, how the local communities present their cultural heritage to the outside visitors affects the way the community members envisage their future. This has been observed in numerous cross-cultural ethnographic cases [13, 14]. Needless to say, how to represent the cultural heritage reflects the present condition of political hierarchies that exist within the society.

Members of local communities have diverse opinions that are positioned in different contexts of their lives. A unified representation of cultural heritage may not be something that some members of the community can easily accept [15]. This may affect the community negatively in both socio-cultural and political domains. Sometimes the cohesiveness within the community is weakened, and some members even decide to leave the community altogether. This is a serious breach of the cultural rights of these members. 


\subsubsection{Identification and Documentation of Cultural Heritage}

Inventories should identify threats that certain elements of cultural heritage are facing. Based on such information, a plan for safeguarding or revitalization can be developed. For this reason, it is important to include in a form for inventorying questions related to the state of viability such as threats to enactment and threats to transmission.

\subsubsection{Danger of Extinction}

According to Karin and Philippe (2003), the new alternative approaches to cultural heritage preservation recognize the importance of preserving vital and living elements of cultures. Because of natural and human factors, developments around cultural heritages, conflict of interest among stakeholders, theft and vandalism, and inappropriate conservational practices, the danger of losing them is sometimes underestimated [16].

Truscott (2000) argued that local communities themselves often do not see the importance of preserving their cultural heritage properties including oral traditions, legends, and languages. They consider their cultural heritage as backward and as a hindrance to their ability to access "modern society" and economic wealth. It is essential, therefore, not only to create a political environment that values and respects minority cultures but also to encourage communities to become aware of their cultural treasures and to help them find ways to preserve those treasures [18].

Royand Kalidindi (2017) stated that rapid growth of urbanization, the pressure of tourism, lack of funds for culture, improper project selection, lack of traditional know-how among conservation professionals (lack of skilled professionals), poor management or handling system of heritages, corruption, and erroneous conservation policy are responsible for the poor performance of heritage conservation projects [19]. Besides, adverse factors that threaten heritage conservation include heritage trafficking, limited community participation in conservation, cultural degradation, and lack of attention from government bodies, and lack of coordination among stakeholders [20]. Other critical issues of heritage conservation encompass indigenous claims of ownership and access to material culture, authentic, original value embodied in material culture [21]; removal of monuments from their original site, damage through the flooding of agricultural land, resettlement programs and rebuilding of urban centers [22].

\subsubsection{Lack of Funds and Experts}

Another problem acknowledged by Navaneethakrishnan (2013) is that custodians of cultural heritage are not always good at organizing or management of funds. On the other hand, those who are experts in organizing and managing funds are not always experts or even interested in cultural heritage. So the solution has been creating collaboration between these two kinds of people: between the cultural heritage custodians and those who are experts in managing and organizing these kinds of projects [23].

Another one which was mentioned by Mancacaritadipura (n.d), the younger generation is less interested in the local culture, so how to overcome this? Mancacaritadipura suggested that this should be included in the school curriculum at local content [24]. Besides the main curriculum, Mike and David (2006) forwarded that awareness creation about the significance and promotion of cultural heritage should be undertaken in schools, colleges, and universities [25]. Another mechanism of securing funds and initiating experts in devising means of discussions regarding the values of cultural heritage on different media such as social media, broadcast media, and printed media. People now mostly watch television whereas formerly they watched some traditional live performances [1].

\subsubsection{Organizational Structure Problem}

As observed in many African countries, states have not yet created an official section and positions in the Department of Culture and Tourism to be specifically responsible for cultural heritage [18]. Truscoot (2000) forwarded that the government may create a subdirectorate of cultural heritage which will make it easier to do long-term programs [17]. Besides, UNESCO (2005) has been identified difficulties in finding qualified human resources to participate in efforts to preserve and develop cultural heritage [1].

\subsection{Opportunities for Safeguarding Cultural Heritage}




\subsubsection{Stakeholders Involvement}

Cultural heritage must be thoughtfully managed if it is to survive in an increasingly globalized world [26]. True partnerships are required between all relevant stakeholders, particularly governments, private tourism sectors, NGOs, and local communities. Tourism stakeholders need to acquire an awareness of cultural heritage management practices, while heritage managers must endeavor to comprehend the complex phenomenon of cultural tourism. Through mutual understanding, both can build on their shared interest in cultural assets, in close consultation with local communities, the ultimate bearers of mankind's cultural legacy [27]. Community-based tourism projects allow for direct communication between communities and the tourism and heritage sectors while sustainably developing cultural assets as tourism products [28].

\subsubsection{Community Participation}

Communities must be actively involved in safeguarding and managing their cultural heritage since it is only they who can consolidate their presence and ensure its future [29]. Each community, using its collective memory and consciousness of its past, is responsible for the identification as well as the management of its heritage. Individual elements of this heritage are bearers of many values, which may change in time. The various specific values in the elements characterize the specificity of each heritage. From this process of change, each community develops awareness and consciousness of a need to look after their common heritage values [30]. Communities, in particular indigenous communities, groups, and, in some cases, individuals, play an important role in the production, safeguarding, maintenance, and re-creation of the intangible cultural heritage. Within the framework of safeguarding the cultural heritage, each State Party shall Endeavour to ensure the widest possible participation of communities, groups, and, where appropriate, individuals that create, maintain, and transmit such heritage, and to involve them actively in its management [31].

\subsubsection{UNESCO Committee and Convention for Safeguarding Cultural Heritage}

Today, even in a world of mass communication and global cultural flows, many forms of cultural heritage are being preserved or conserved, in every country and every corner of the world [32]. Other forms and elements of cultural heritage resources which are more fragile, and some even endangered needs measures called for by the UNESCO Convention of safeguarding heritage properties at the national and international levels can help communities to ensure that their heritage remains available to their descendants for decades and centuries to come [33]. The Convention recognizes that the communities, groups, and, in some cases, individuals who safeguard and maintain cultural heritage must be its primary stewards and guardians, but their efforts can be supported or undercut by State policies and institutions [3]. The challenges facing such communities, and those who work on their behalf, are to ensure that their children and grandchildren continue to have the opportunity to experience the heritage of the generations that preceded them and that measures intended to safeguard such heritage are carried out with the full involvement and the free, prior and informed consent of the communities, groups, and individuals concerned [34].

\section{Methods And Materials}

\subsection{Description of the Study Area}

North Shoa of Amhara regional state is located in the central part of Ethiopia, north of the capital city of Ethiopia, Addis Ababa. The traditional administrative areas known as Bulga, Angolela, Merhabete, Ensaro, Jiru, Ankober, Tegulet, Menz and Yifat are part of North Shoa (Semein Shoa). North Shoa Zone is blessed with plenty of cultural, historical, and natural tourism resources. The zone is also endowed with natural resources such as The Menz Guassa Community Conservation Area and the Wof-Wash Afromontane Hotspot Forest. There are mountains in the region, namely Mt.Abeye (4005), Mt.Megezez (3878), Mt. Kundi (3730) having the potentials to develop trekking activities [35].

\subsection{Research methodology}

The research employs both qualitative and quantitative research approaches which is a mixed research approach. A descriptive, exploratory and explanatory method of cross-sectional research design was used. The quantitative data was collected through a questionnaire survey whereas qualitative data was gathered using interviews, site observations, focus group discussions and 
document analysis. The subjects of this study include the local communities, North Shoa Zone and woredas Culture and Tourism office staff, authority for research and conservation of cultural heritage (ARCCH) and religious institutions having direct and indirect involvement in tourism activities. Both purposive and systematic random sampling was employed to choose samples from the study population. Informants for interview and focus group discussion were selected based on their knowledge and closeness to the research problem under study. To collect data through in-depth interviews, a total of 10 purposively selected individuals (from North Shoa Culture and Tourism, Debre Berhan Culture and Tourism Office, Angolola and Tera Culture and Tourism Office, Ankober Culture and Tourism Office, and $\mathrm{ARCCH}$ ) were interviewed.

The data collected from primary and secondary sources are tallied, tabulated and analyzed through descriptive statistical tools and descriptive narrations to analyze the data gathered from the interview. Qualitative data which was collected from open-ended questions, which the respondents will answer by using their own words, was coded into a set of categories developed from identified commonalities.

\subsection{Reliability and Validity Analysis}

The research has conducted the reliability and validity test to assure the appropriateness of the instrument and the consistency of the results using the pilot study. The validity of the research explains how well the collected data covers the actual area of investigation [36]. Hence, to assure the validity of the instruments the research used standardized questionnaires and the items were checked by consulting the researcher advisors and subject area experts.

Besides, the reliability concerns the extent to which a measurement of a phenomenon provides stable and consist result [37]. or it is all about the consistency of the result [36] to measure inter-item homogeneity of each construct using Cronbach's alpha value greater than or equal to .70 [38] and the inter-item correlations were greater than or equal to .30 [39] were included to collect data and included in the analysis. Besides, Sharma (2016) classified the reliability statistics depending on the Cronbach alpha value: $\alpha \geq .90=$ Excellent, $.90>a \geq .80=$ Good, $.80>a \geq .70=$ Acceptable, $.70>a \geq .60=$ Questionable, $.60>a \geq .50=$ Poor and $a<.50=$ Unacceptable.

In the present study, the reliability analysis was made by employing 58 observations which are nearly $15 \%$ of the total sample population [i.e., $15 \% * 384=57.6$ ) for a pilot survey. The reliability of the survey instruments was estimated based on Cronbach alpha measure of internal consistency as indicated in the table below. The items from each of the constructs having very low inter-item correlation below.30 were removed. The reliability analysis revealed the Cronbach alpha coefficient that exhibited the consistency of the results that ranges from .741 to .802 that made the result acceptable based on [38, 39].

\section{Results And Discussion}

\subsection{Respondents Characteristics}

As far as this study, out of the respondents, the majority of them were males that account for $143(72.2 \%)$ whereas $55(27.8 \%)$ were female respondents which shows the majority of the respondents engaged in and around the heritages are dominated by males. Besides the gender category of the respondents of the present study, the age group and education level of respondents were assessed. Thus, from the respondents, the majority were youngsters under 18-35 years of age that account for 175 (79.3\%) followed by ages between 36 - 45 which was about 31 (15.7\%) and above 46 years old that account for $10(5.1 \%)$ respectively. The survey indicates the majority of employees working and residing around cultural heritages are almost youngsters which can be basic to apply cultural heritage conservation practices for better off.

The majority of the respondents were having a university degree and above that accounting for $126(63.6 \%)$ followed by a college diploma $(31 ; 15.7 \%)$, secondary school and elementary school which accounts for $25(12.6 \%)$ and $16(8.1 \%)$ respectively.

As depicted below in the table, of the respondents 68 (34.3\%), $52(26.3 \%)$ and $44(22.2 \%)$ of the respondents reside in and around heritage sites namely, Ankober Medahnealem, Koremash and Goze whereas few respondents accounted for 34 (17.2\%) lived in Angolela Kidanemihret area. Regarding the livelihood strategy people employed, the majority of the respondent led their household through employment in government offices followed by engaging in agriculture and working as a private employee that accounting for $61.6 \%, 12.1 \%$ and $9.6 \%$ respectively. The respondents who employed tourism and hotel, and trade as a means of livelihood accounted for $8.6 \%$ and $8.1 \%$ respectively were found low in the study sites.

Page $6 / 22$ 


\subsection{Practices of Cultural Heritage Conservation}

As depicted below, the finding indicates $12.1 \%, 30.8$ and $15 \%$ of respondents strongly disagreed, disagreed and undecided respectively whereas $33.8 \%$ and $7.6 \%$ of respondents agreed and strongly agreed with the existence of an attempt at cultural heritage conservation in your areas. The result shows there is no attempt to conserve the heritage, so the stakeholders shall show their endeavors to conserve heritages. Unlike the finding of the present study, Ekwelem, Okafor and Ukwoma (2011) pointed that the preservation of cultural heritage properties enhances historical and cultural continuity, fosters social cohesion, enables to visualization of the past and envisioning the future, and hence it is indispensable for sustainable development[40].

The finding revealed that the local community has a sense of belongingness and identity to the cultural heritage of your area as it is portrayed by the respondents' response exhibited by $34.3 \%$ and $7.1 \%$ of agreement and strong agreement. In contrast, 10.6 and 26.8 percent of respondents disagree and strongly disagree with the sense of belongingness communities had about cultural heritages. The rest $21.2 \%$ of respondents remain undecided.

The practice of cultural heritage conservation is not based on research in the study $16.2 \& 38.4$ percent of the respondents strongly disagreed and disagreed whereas $18.2 \%$ and $4.5 \%$ of the respondents agreed and strongly agreed that researches are done before putting conservation into practice. Therefore, the finding demands in-depth and strong research to develop conservation guidelines and undertake conservation activities in heritage sites that need significant conservation activities. According to Garrod and Fyall (2000), conservation management should consider timeliness and managerial prudence. The timeliness concept stated that conservation funds should be allotted time to save high conservation costs in the future. From the managerial prudence angle, parallel measures or techniques should be designed to prevent further deterioration [41].

As the findings of the present study conducted revealed $10.1 \%$ strongly disagreed and $29.8 \%$ disagreed that conservations are undertaken without due consideration of originality of buildings in the study sites which shows the majority of the respondents that accounts for about $39.9 \%$ of the respondents. Among respondents, $30.3 \%$ agreed and $7.1 \%$ (total of $37.4 \%$ ) agreed that the authenticity of the heritage buildings is considered in due while undertaking conservation activities. As the study revealed there is no such significant difference between those who agreed and disagreed though disagreements were slightly higher in percentage and a significant number of respondents were unable to decide and fail to either of the two categories that accounted for $22.7 \%$.

Besides, regular follow-up of existing situation status for conservation hasn't been made with $20.7 \%$ and $37.9 \%$ of strong disagreements and disagreements that revealed the majority whereas $22.2 \& 4 \%$ of them replied as there is regular follow up. Similarly, capacity building training on heritage conservation is not delivered at different times to the communities, conservationists and other key stakeholders that are exhibited by a total of $65.7 \%$ level of disagreement (where 26.3 replied strong disagreement and $29.4 \%$ replied disagreement scale category). Only $17.7 \%$ of respondents were found in the agreement response category whereas $16.7 \%$ were unable to fall in the two categories either. The finding of this study revealed that there is a low-level practice of cultural heritage which needs to be improved. This result implication was supported by the conservation of heritages require the three most important elements of heritage conservation underlined by professionals (curators, academics and consultants) are training and expertise of maintenance staff, budget and financial planning, and conservation plan [42].

\subsection{Challenges of Cultural Heritage Conservation}

This study was also concerned about the various barriers the hinder cultural heritage conservations practices for better management and sustainability of cultural heritages in the selected cultural heritage sites of North Shewa Zone. Thus, to identify these factors, factor analysis was employed to extract the list of factors and to group each of the linear components onto each factor if found significant.

A total of 22 items or linear components factors (variables) were employed after checking the reliability of items in the pilot survey. Those variables were coded as: 01 - The local community have no positive attitude towards cultural heritages; 02- The local community are not concerned to the cultural heritages of your area; 03- Population growth and settlement programs have impacts on cultural heritages of the area; 04- There is conflict of interest among stakeholders to safeguard the cultural heritage; 05- There is a practices of heritages conservation without the involvement of professional; 06- There is the practice of illicit trafficking of cultural objects; 07- The cultural heritages of the area are not promoted for sustainable tourism development; 08- There is the practice of

Page $7 / 22$ 
farming in and around the cultural heritages in your locality; 09- There is adequate budget/ financial allocation for conservation of cultural heritages; 10- Little concern of government and local authorities about the heritage in your area; 11- Professionals lack enough commitment to engage in conservation practices; 12 - Medias failed to expose the problems of heritages to the community in time; 13- Travel agents and tour operators are negligent to the sustainability of heritage; 14- There is inappropriate conservation practices of cultural heritage; 15- There is lack of buffer zone demarcations of the heritage sites; 16 - Natural catastrophes and climate variations (flooding, frost, acidic rain, storm, heat from the sun) deteriorate cultural heritages; 17- Development projects such as buildings, roads affect the sustainability of heritage; 18- The heritage hosts more than its carrying capacity during different events; 19- Funding agencies lack willingness to provide aids and loans to cultural heritages; 20 - There is no regular monitoring and evaluation of cultural heritage status by the concerned body in your area; 21- The growth of vegetation over the heritages is the challenges of heritages, and 22- The heritages are challenged by biological factor such as rat and other biological organisms.

The assumptions of relationship, randomness and sampling adequacy were checked in the analysis of exploratory factor analysis (EFA).

The descriptive statistics revealed that all the 22 linear component factors or variables have a mean value greater than 3 with a range varied from 3.41 to 3.95 and Std. The deviation between .776 and 1.332 for a total of 198 valid observations made for analysis. And, there was no missing data in the analysis.

The Kaiser-Meyer-Olkin Measure of Sampling Adequacy and Bartlett's Test of Sphericity also indicated that the sample size employed in this study was adequate and the assumption is met with $\mathrm{KMO}$ and Bartlett's Test of Sphericity value of .768 and Sig.= .000 . A value varies between 0 and 1 where the value close to 1 indicates that patterns of correlations are relatively compact and so factor analysis should yield distinct and reliable factors. Kaiser (1974) recommends accepting values greater than 0.5 as acceptable. Hence, the current value of KMO Bartlett's Test of Sphericity meets the assumption [43].

The communalities table also presented the relationship of one of the variables with the other variables before rotation with which a value greater or equal to .30 indicates the employed sample is acceptable and results will not be distorted. The current finding has confirmed this assumption of factor analysis with the value ranging from .315 to .784 which is significantly above .30 .

\subsubsection{Factor Extraction and Variance Explained}

The present finding has shown in the total variance explained table, as the total variance explained, was $59.511 \%$ which is attributed to the 7 factors extracted out of 21 linear components variables included in the model with Eigenvalues greater than 1. Hence, from the table, the Rotation Sums of Squared Loadings indicated that the first factor contributed about $14.726 \%$ and the $2^{\text {nd }}$ contributes $9.412 \%$ whereas the $3^{\text {rd }}$ and $4^{\text {th }}$ factors accounted for $8.808 \%$ and $7.503 \%$ of variance explained. The $5^{\text {th }}, 6^{\text {th }}$, and $7^{\text {th }}$ factors contributed to about $7.222 \%, 6.509 \%$ and $5.325 \%$ of variance explained in cultural heritage conservation. The cumulative percentage variance explained from the 7 factors was found to be $59.511 \%$ after an orthogonal rotation.

\subsubsection{Factor Rotation}

The rotated factor matrix indicates the rotated component matrix (also called the rotated factor matrix in factor analysis) which is a matrix of the factor loadings for each variable on to each factor. The values below .40 were suppressed while extracting the factors and are not displayed in the rotated component matrix and the factor loadings were sorted by size. The orthogonal rotation was used with the assumption that the variables are independent of each other [44]. Before rotation, most variables loaded highly onto the first factor (21.554\% variance explained) and the remaining factors didn't really get a look in. However, the rotation of the factor structure has clarified things considerably with the equivalence of variance explained. The suppression of loadings less than 0.4 and ordering variables by loading size was also made to make interpretation considerably easier.

As it can be depicted in the rotated matrix table, there are seven components or factors that have been extracted as a factor hindering the applicability of cultural heritage conservation in the study areas of North Shoa.

Hence, Principal Component factor analysis with Varimax rotation was conducted to assess the underlying structure for the 22 items of the challenges of cultural heritage conservation practices. The assumption of independent sampling was met. The assumptions of normality, linear relationships between pairs of variables, and the variables being correlated at a moderate level were checked.

Page 8/22 
Seven factors were extracted after rotation, the first factor accounted for $14.726 \%$ of the variance, the second factor accounted for $9.412 \%$, the third factor accounted for $8.808 \%$, the fourth factor accounted for $7.503 \%$. Moreover, $7.222 \%, 6.509 \%$ and $5.325 \%$ of variance explained were attributed by the $5^{\text {th }}, 6^{\text {th }}$ and $7^{\text {th }}$ components factors. The following table displays the items and factor loadings for the rotated factors, with loadings less than .40 omitted to improve clarity.

As it is indicated in the table below, the first factor consisted of seven items which are related to lack of proper management, monitoring and evaluation whereas the second factor which is a cluster of three variables was related to lack of stakeholder involvement and population settlement. Besides, the third factor encompasses two items which are related to lack of government concern and professional commitment, and the fourth factor which again comprises of three items is related to lack of community concern, illicit trafficking and promotion towards sustainable development. The fifth and the sixth factors consist of two variables each which are related to poor destination management and conservation practice, and natural catastrophes and agricultural practices respectively whereas the seventh factor encompasses only a single variable that is related to lack of communities' positive attitude towards cultural heritage.

Similar to the present study, heritage properties can be affected by the impacts of visitors such as overcrowding which may result in wear and tear including trampling, handling, humidity, temperature, pilfering and graffiti [41].

After the exploratory factor analysis was conducted and the seven factors were extracted the multiple linear regression was applied to confirm which factors affect the practice of cultural heritage conservation in the study area. The multiple linear regression to confirm the extracted seven component factors is explained and analyzed below.

\section{Assumptions of Multiple Linear Regression}

1. The relationship between the independent variable and dependent variables is linear. This assumption was confirmed as reflected by the scatter plot/dot options that show the relationship is linear for all independent variables: lack of proper management, monitoring and evaluation, lack of stakeholder involvement and population settlement, lack of government concern and professional commitment, lack of community concern, illicit trafficking and promotion towards sustainable development, poor destination management and conservation practice, natural catastrophes and agricultural practices, and the local community have no positive attitude towards cultural heritages for Cultural Heritage Conservation.

2. There is no multicollinearity in the data set. Multicollinearity exists when the correlation coefficient $\mathbf{r}$ between independent variables is above 0.80 . Hence, no independent variable was found stakeholder integration was not found to have multicollinearity problem with each other with all below .80 where the highest Pearson correlation value of .688. Besides, the multicollinearity issue can be checked by VIF and tolerance level in which multicollinearity will not be a problem where VIF is below 10 and tolerance level > .20 [45]. Hence, VIF and Tolerance are found with the acceptable region.

3. The values of the residual are independent. The residuals of the data set in the sample stratum found independent or uncorrelated which can also be tested based on Durbin-Watson statistics i.e., above one and below 3. The Durbin Watson statistics is 1.821.

4. The assumption of homoscedasticity: the assumption that shows the variation in the residual is a similar constant at each point of the model. This can be shown by the normality probability curve of the scatter plot.

5. The values of the residual are normally distributed. This assumption can be tested by looking at the p-p plot for the model. The closer the dote lies to the diagonal line; the closer to normal the residuals are distributed. The normal p-p plot dotes line indicates that the assumption of normality has not to be violated.

\subsubsection{Regression Results}

The Pearson`s correlation table indicates, there was a significant relationship between the independent variables and the dependent variable; Cultural heritage conservation at a .05 level of significance. However, lack of stakeholder involvement and population settlement, poor destination management and conservation practice and the local community have no positive attitude towards cultural heritages were not significantly correlated with the cultural heritage conservation practice $(r=.057, \operatorname{sig}=.212 ; r=-.008$, sig. $=$ .458 and $r=.016$, Sig=.410). Thus, the indicators were removed from the regression model. 
The ANOVA table exhibits the goodness of fit of the model and it revealed the model is appropriate and the introduction of the independent variables has improved by at least one predictor with the F-statistics value of $3.525(P=.001)$ significant at $1 \%$ level of significance. Thus, the model is the best-fitted model presented the regression that presents the significant independent variables that significantly explain the dependent variable.

The model summary table shows the predicted variable i.e., Practices of Cultural Heritage Conservation is explained by the introduced independent variables viz., natural catastrophes and agricultural practices, lack of community concern, illicit trafficking and promotion towards sustainable development, lack of government concern and professional commitment, and lack proper management, monitoring and evaluation for about $\mathbf{7 . 9 \%}$ with an adjusted $\mathrm{R}$ square value of $\mathbf{. 0 7 9}$. The variance explained in the model summary table is also supported by the coefficients table that exhibited some of the extracted factors that were significant that contribute to the practices of conservation of cultural heritage sites.

The coefficient result shows that the largest $\boldsymbol{\beta}$ value is the greatest predictor of heritage conservation. Among the independent variables, lack of community concern, illicit trafficking and promotion towards sustainable development was found significant strongest factor affecting practices of cultural heritage conservation $(\beta=-.213, p<.05)$ followed by natural catastrophes and agricultural practices $(\beta=-.132, p<.05)$. Furthermore, there was a negative relationship between lack of community concern, illicit trafficking and promotion towards sustainable development, and natural catastrophes and agricultural practices with the predicted variable i.e., practices of cultural heritage conservation.

As far as this study was concerned, lack of community concern, illicit trafficking and promotion towards sustainable tourism development with $\mathrm{B}=-213$; Sig. $=.002$ and natural catastrophes and agricultural practices in and around the cultural heritages with $\mathrm{B}=$ -.132 ; Sig. $=.026$ were found significant factors affecting the heritage conservation practices in the study areas. This finding was confirmed by the previous studies that revealed air pollution; biological causes like invasive intervention, humidity and vandalism have negative consequences on the survival of heritage tourism. The present finding was also in line with the findings of Irandu and Shah (2016) that portrayed the cultural heritage conservation of Kenya faced challenges such as funding, poor enactment of policies, land grabbing and lack of adequate trained personnel [46]. Unlike the present study, as noted in the work of Eken, Taşcl, and Gustafsson (2019) public participation along with governmental strategies is vital to decide preventive conservation. Their finding indicated that local communities have an awareness regarding the significance and preservation of the World Heritage Site of Visby, but they were not adequately cognizant of the practical aspect of preservation. The other issues raised by the authors are difficulties with respect to guidance and promotion of regular maintenance. Besides, restoration works have been carried out without a detailed report of the current condition of the cultural heritage [47]. On the opposite, the interview was found in line with the aforementioned previous study revealing disintegration of the heritage concerned authorities, the poor intervention of the government and strong collaboration of the government with the local communities and local and regional government. Besides, the political implication in the understanding of heritages was also nailed our challenge in the conservation of cultural heritage. Unlike the present finding, the study of Tweed and Sutherland (2007) conserving heritage properties contributes to the sustainability of the built environment, and it is a crucial element of the cultural identity of the community which describes the character of a place [48].

The cultural heritages understudy is facing various natural and manmade problems which were verified by the interview made with the Authority for Research and Conservation of Cultural Heritages (ARCCH) Heritage Restoration and Conservation Department that revealed structural problems of the heritage authority from federal to the local level, lack of skilled manpower both in quantity and quality in the authority as well as the availability of under the authority of existing proclamations such as private heritages and need for expanding construction. This finding was supported by the technical aspects such as limited availability of experts (lack of skilled forces, absence of educational training for new skill, and lack of technical staffs in the heritage maintenance team) and availability of original or authentic materials were the major constraints in conservation projects. Besides, the interviewees added lack of sufficient funds for restoration and conservation and the difficulty of conservation of heritages in and nearby urban areas due to urbanization and urban renovation were significant challenges for conservation. Moreover, the unavailability of raw materials for restoration and maintenance of heritages keeping authenticity was found a very serious problem in the applicability of cultural heritage conservation practices [49]. Though the regression output didn't confirm the factor explored from Exploratory Factor Analysis i.e., lack of community concern and positive attitude towards cultural heritages, the interview identified that communities disregard about cultural values of the heritages and need to replace them with modern buildings, and hiding movable heritages are problems in escalating conservation efforts. An ideal example is the church of Ankober Medahnealem Church where only remnants or ruins of buildings are visible and the historical old church was demolished by the communities to replace it with the new modern buildings. Generally, the finding of the

Page 10/22 
present study indicates the various challenges that should be overcome in order to assure the sustainability of cultural heritage. This was also supported by the study of [48], whose heritage conservation theme encompasses technical, environmental, organizational, financial and human issues.

\section{Practical Implications}

There should be mechanism and plan to evaluate, follow up and supervise the conservation status of heritages side by side with the activities of heritage inventory made each year in each study are by the respective woreda. In this regard, a study suggested that an urgent response from the government should be given in collaboration with the societies around the heritage sites [50]. Appropriate guidelines for conservation should be developed based on research and scientific evidences to escalate the conservation practices. In line with this, to make the conservation effort effective the right heritage management professionals and appropriate mapping guidelines should be hired to conduct for the management of cultural heritage conservations and preservations [51, 50]. Besides, conservation activities should be made in collaboration by allocating sufficient budget and human resources equipped with latest technology and required raw materials to help keep the authenticity of the heritages. This is supported by the finding that revealed heritage conservation should also be functioned through the provision of budgets, training, technical support and interventions [52, 50]. Furthermore, heritage conservation funds should be organized institutionally and come into practice to support conservation efforts. The local communities, the private travel and tourism organizations and government bodies should be engaged in the planning, execution and monitoring of heritage conservation and renovation process. In addition, better platforms for stakeholder collaboration should be developed and management of conflict of interest threats should be seriously addressed. The study of [53] recommended that the function of involving the local communities and all other key stakeholders in decision making and the view of right participation which in turn can provide equal the capacity to participate and raising the stakeholder capabilities $[54,55]$.

\section{Conclusion}

Though there are few attempts especially at Angolela Kidanemihret Site at King Sahle Sellasie Palace and Goze Mosque, the practices of cultural heritage conservation were found very low which needs to be enhanced so as to assure the existence of cultural heritages sustainable. The finding of this study revealed local communities feel as the heritage belongs to them and consider them as it is their identity. On the other hand, conservation of activities was not based on research, conservation practices and status of heritage follow up are not made on regular basis and capacity buildings are not provided for the sustainable conservation of cultural heritages in the study areas.

The status and practice of cultural heritage conservation are hindered by lack of community concern, illicit trafficking and promotion towards sustainable tourism development and natural catastrophes and agricultural practices in and around the cultural heritages were found significant factors affecting the heritage conservation practices in the study areas. Besides, lack of government concern, community interest, lack of appropriate funding and skilled manpower were also found significant factors that hinder the practices of conservation of cultural heritage. Moreover, the structural weakness of the heritage-related government institutions and political implication of leaders and the urbanization and urban renovation programs added are exacerbating the existence and practices of cultural heritage conservation.

Generally, the poor conservation practices of cultural heritages and insufficient commitment and practice of concerned bodies to conserve cultural heritages exacerbated by various manmade and natural factors demand strong and vivid solutions to the problems to reverse the existing severe conditions of the cultural heritage. Besides, the challenges that hampered the conservation practices and escalate damages to them should be tackled to make the heritages useful for the existing people and conserve sustainably for the next generation.

\section{Declarations}

Availability Data and Materials: Not Applicable.

Competing Interest: The authors declare that the study has no any conflict of interest.

Funding: This research received internal/ local funding from Debre Berhan University. 
Author Contributions: Kassegn Berhanu develops proposal and conceptualise the paper; Habtamu Mekonnen reviews the literature, prepare items and edit the manuscript; Zemenu Bires writes the analysis and discussion part of the manuscript.

Ethical Concern: The study was investigated as per the research guidelines of Debre Berhan University, Ethiopia, and the final findings was presented to the university research committee and got acceptance on 20 October 2021.

Acknowledgments: First of all, we would like to express our deepest gratitude to the Omnipotent God for the strength and determination to accomplish this academic research paper. Praise God! God Grace!

We are really delighted to express sincere gratitude to Debre Berhan University, College of Social science and Research and Community Service Directorate for funding, duplicating questionnaire, writing letters to concerned offices and stakeholders during data collection.

Last but not least, we are also indebted to all the respondents (local communities, culture and tourism offices, Authority for Research and Conservation of Cultural Heritage (ARCCH), Angolola Seminesh Kedanemihiret Chruch, Goze and Koremash Mosque) who participated in the interview sessions and filling the questionnaire or survey. Thank you for your invaluable information, precious time, enthusiasm and cooperation.

The Authors would love to express their genuine thanks to Rashmi Jenna JEO Assistant of Heritage Science. [Editorial teams and anonymous reviewers to be acknowledged].

\section{References}

[1] UNESCO, 2005. Globalization and intangible heritage, Belgium

[2] Kurin, R. (2004). Safeguarding Intangible Cultural Heritage in the 2003 UNESCO Convention: a critical appraisal. Museum international, 56(1-2), 66-77.

[3] UNESCO, 2007. Safeguarding Intangible Heritage and Sustainable Cultural Tourism: Opportunities and Challenges, UNESCOEIIHCAP Regional Meeting, Hué, Viet Nam,

[4] FDRE (Federal Democratic Republic of Ethiopia). 1997. The Federal Democratic Republic of Ethiopia Cultural Policy, Addis Ababa: FDRE.

[5] Ministry of Culture and Tourism, ARCCH and UNESCO, 2007. Meeting on inventorying

[6] Mengistu, G., 2008. Heritage tourism in Ethiopia, Addis Ababa, Ethiopia. Intangible cultural heritage in Ethiopia, Djibouti and Somalia, Addis Ababa, International Journal of Heritage Studies, 7(4).

[7] Pietrobruno, Sheenagh (n.d), Cultural Research and Intangible Heritage, Culture Unbound, Volume 1, (2009), 227-247. Hosted by Linköping University Electronic Press:

[8] Nesbeth, G., 2013. Art and globalization: the place of intangible heritage in a globalizing

environment, Ph.D. dissertation. University of South Africa

[9] Lévi-Strauss., 2011. Anthropology Confronts the Problems of the Modern World, Paris

[10] ICOM-CC (International Council for Museums - Conservation Committee), 2008. Terminology to Characterize the Conservation of Tangible Cultural Heritage. Accessed September 14, 2020, retrieved from http://www.icom-cc.org/242/about-icom-cc/what-isconservation.

[11] Stiffman, E., 2015. Cultural Preservation in Disasters, War Zones. Presents Big Challenges in the Chronicle of Philanthropy.

[12] Herzfeld, M. (1991). A place in history: social and monumental time in a Cretan town. Princeton University Press.

[13] Babb, F. E. (2012). Theorizing gender, race, and cultural tourism in Latin America: a view from Peru and Mexico. Latin American Perspectives, 39(6), 36-50.

Page $12 / 22$ 
[14] Olwig, K. F. (1999). The burden of heritage: Claiming a place for a West Indian culture. American Ethnologist, 26(2), 370-388.

[15] During, R. (Ed.). (2011). Cultural heritage and identity politics. Silk Road Research Foundation.

[16] Czermak, K., Delanghe, P., \& Weng, W. (2003, November). Preserving intangible cultural heritage in Indonesia. In Conference on Language Development, Language Revitalization and Multilingual Education in Minority Communities in Asia (pp. 1-8).

[17] Truscott, M., 2000. 'Intangible values as heritage in Australia', ICOMOS Newsletter, Mar-July (www.international.icomos.org/truscott_eng.htm, accessed on $12^{\text {th }}$ July 2020)

[18] Munjeri, D., 2000. 'Intangible heritage in Africa: could it be a case of 'much ado about nothing'?' ICOMOS Newsletter, March-July (www.international.icomos.org/munjeri_eng.htm, accessed on July 20, 2020).

[19] Roy, D. and Kalidindi, S., 2017. Critical challenges in the management of heritage conservation projects in India. Journal of Cultural Heritage Management and Sustainable Development, 7(3), pp. 290-307.

[20] Berhanu, E., 2018. Potentials and challenges of religious tourism development in Lalibela, Ethiopia. African Journal of Hospitality, Tourism and Leisure, 7 (4).

[21] Wharton, G., 2005. Indigenous claims and heritage conservation: an opportunity for critical dialogue, Public Archaeology, 4 (2-3), 199-204. http://dx.doi.org/10.1179/pua.2005.4.2-3.199

[22] Le Mentec, K., 2006. The Three Gorges Dam Project-Religious Practices and Heritage Conservation. A study of cultural remains and local popular religion in the xian of Yunyang (municipality of Chongqing). China Perspectives, 2006(65).

[23] Navaneethakrishnan, S., 2013.Preservation and Documentation of Intangible Cultural Heritage: the Strategic Role of the Library and Information Science Professionals in Sri Lanka. Journal of the University Librarians Association of Sri Lanka, 17 (1)

[24] Mancacaritadipura, G.(n.d). Safeguarding the Intangible Cultural Heritage of Indonesia: Systems, Schemes, Activities and Problem

[25] Mike, R. and David, P., 2006. Tourism, culture and sustainable development, UNESCO, Spain, Madrid

[26] Xulu, M., 2007. Indigenous Culture, Heritage and Tourism: An Analysis of the Official Tourism Policy and Its Implementation in the Province of Kwazulu-Natal: a Thesis submitted To the Faculty of Arts in Partial Fulfilment of the Requirements For the Degree of Doctor of Philosophy in The Centre for Recreation and Tourism at the University of Zululand, retrieved on $3^{\text {rd }}$ September 2020.

[27] Eleonora, L., 2007. Intangible Cultural Heritage Valorization: A New Field for Design Research and Practice; Italia, Milano

[28] Karin. C. and Philippe. D., 2003. Preserving intangible cultural heritage in Indonesia A pilot project on oral tradition and language preservation UNESCO Jakarta, Indonesia

[29] UNESCO, 2008. Safeguarding Intangible Heritage and Sustainable Cultural Tourism: Opportunities and Challenges, Bangkok

[30] European Construction Technology Platform., 2008. Cultural Heritage guide, technology integration division T RAV E L W O R L D NEWS-SECTIO

[31] UNESCO-ICOMOS Documentation Centre, 2011. Convention for the Safeguarding of Intangible Cultural Heritage

[32] R i c h a r d, K ., 2004. Museums and Intangible Heritage Culture Dead or Alive? : ICOM news

[33] Jamieson,W., 2000. The Challenges of Sustainable Community Cultural Heritage Tourism, Asian Institute of Technology, Bangkok, Thailand

[34] Boonyakiet, C., 2011. "Introduction to the Intangible Cultural Heritage and Museums Field School by Alexandra Denes, Anthropology Centre, Thailand" Intangible Cultural Heritage and Museums Learning Resources 
[35] Hailu, W.A.,N.D. Prospects for Environmental Protection and Eco-Tourism In Semen Shewa. Retrieved from http://www.cyberethiopia.com/net/docs/hailu.pdf

[36] Taherdoost, H. (2016). Validity and Reliability of the Research Instrument; How to Test the Validation of a Questionnaire/Survey in a Research. SSRN Electronic Journal. https://doi.org/10.2139/ssrn.3205040

[37] Carmines, E. G., \& Zeller, R. A. (1979). Reliability and validity assessment. Sage publications.

[38] Cronbach, L. J., \& Warrington, W. G. (1951). Time-limit tests: Estimating their reliability and degree of speeding. Psychometrika, 16(2), 167-188.

[39] Tavakol, M., \& Dennick, R. (2011). Making sense of Cronbach's alpha. International Journal of Medical Education, $2,53$.

[40] Ekwelem, V. O., Okafor, V. N., \& Ukwoma, S. C. (2011). Preservation of cultural heritage: The strategic role of the library and information science professionals in South East Nigeria. Library Philosophy and Practice, 1.

[41] Garrod, B., \& Fyall, A. (2000). Managing heritage tourism. Annals of Tourism Research, 27(3), $682-708$.

https://doi.org/10.1016/S0160-7383(99)00094-8

[42] Idrus, A., Khamidi, F., \& Sodangi, M. (2010). Maintenance management framework for conservation of heritage buildings in Malaysia. Modern Applied Science, 4(11), 66-77.

[43] Kaiser, H. F. (1974). An index of factorial simplicity. Psychometrika, 39(1), 31-36.

[44] Field, A. (2009). Discovering statistics using spss third edition.

[45] Miles, E., \& Crisp, R. J. (2014). A meta-analytic test of the imagined contact hypothesis. Group Processes \& Intergroup Relations, $17(1), 3-26$.

[46] Irandu, E., \& Shah, P. (2016). Development of cultural heritage tourism in Kenya: a strategy for diversification of tourism products. Conservation of Natural and Cultural Heritage in Kenya. A Cross-Disciplinary Approach, 154-171.

[47] Eken, E., Taşcı, B., \& Gustafsson, C. (2019). An evaluation of decision-making process on maintenance of built cultural heritage: The case of Visby, Sweden. Cities, 94, 24-32.

[48] Tweed, C., \& Sutherland, M. (2007). Built cultural heritage and sustainable urban development. Landscape and urban planning, $83(1), 62-69$.

[49] Azizi, N. Z. M., Razak, A. A., Din, M. A. M., \& Nasir, N. M. (2016). Recurring Issues in Historic Building Conservation. Procedia Social and Behavioral Sciences, 222, 587-595. https://doi.org/10.1016/j.sbspro.2016.05.217

[50] Tilahun, M. (2019). Survey of Cultural Heritages in Soddo woreda south guragea zone Ethiopia.

[51] Nel, J. L., Roux, D. J., Abell, R., Ashton, P. J., Cowling, R. M., Higgins, J. V., Thieme, M., \& Viers, J. H. (2009). Progress and challenges in freshwater conservation planning. Aquatic Conservation: Marine and Freshwater Ecosystems, 19(4), $474-485$.

[52] Adane, Y. (2019). Practices and Challenges of Cultural Heritage Conservation in Ethiopia: The Case of Ankober, North Shewa Zone.

[53] Aas, C., Ladkin, A., \& Fletcher, J. (2005). Stakeholder collaboration and heritage management. Annals of Tourism Research, 32(1), 28-48. https://doi.org/10.1016/j.annals.2004.04.005

[54] Abebayehu, B. (2021). Key stakeholders'integration for religious heritage site conservation: the case of Angolela Seminesh Kidanemihret Monastery North Shewa Zone, Ethiopia.

[55]Jamal, T. B., \& Getz, D. (1995). Collaboration theory and community tourism planning. Annals of Tourism Research, 22(1), 186204.

\section{Tables}

Page 14/ 22 
Tables 2 and 7 are not available with this version

Table 1: Reliability Analysis using Cronbach Alpha

\begin{tabular}{|lllc|}
\hline Variable & $\begin{array}{l}\text { Cronbach's } \\
\text { Alpha }\end{array}$ & $\begin{array}{l}\text { No of the items } \\
\text { deleted }\end{array}$ & $\begin{array}{l}\text { Total number of tested } \\
\text { items }\end{array}$ \\
\hline Status of Cultural Heritage Conservation & .752 & 1 & 7 \\
\hline $\begin{array}{l}\text { The practice of Cultural Heritage Conservation } \\
\text { Challenges of Cultural Heritage Conservation }\end{array}$ & .741 & -802 & 1 \\
\hline $\begin{array}{l}\text { Stakeholders' role in Cultural Heritage } \\
\text { Conservation }\end{array}$ & .750 & - & 22 \\
\hline
\end{tabular}

Source: Survey, 2021

Table 3: Sex, age and education level $(\mathrm{N}=198)$

\begin{tabular}{|llll|}
\hline Demographic Variables & Category & Frequency & Percentage (\%) \\
\hline Gender & Male & 143 & 72.2 \\
\cline { 2 - 4 } & Females & 55 & 27.8 \\
\hline Age & $18-35$ & 157 & 79.3 \\
\hline \multirow{2}{*}{ Educational Status } & $36-45$ & 31 & 15.7 \\
& $>46$ & 10 & 5.1 \\
\cline { 2 - 4 } & Elementary school & 16 & 8.1 \\
\cline { 2 - 4 } & Secondary school & 25 & 12.6 \\
\cline { 2 - 4 } & College diploma & 31 & 15.7 \\
\cline { 2 - 4 } & Bachelor degree \& above & 126 & 63.6 \\
\hline
\end{tabular}

Source: Field Survey, 2021

Table 4: Place Residence and Livelihood Strategy ( $=198)$ 


\begin{tabular}{|llll|}
\hline Place where respondent living in & Residence & Frequency & Percentage (\%) \\
\cline { 2 - 4 } & Ankober Medahnealem & 68 & 34.3 \\
\hline Koremash & 52 & 26.3 \\
\hline Goze & 44 & 22.2 \\
\hline Angolela Kidanemihret & 34 & 17.2 \\
\hline Means of livelihood & & \\
\hline Livelihood Strategy & Frequency & Percentage \\
\hline & & 12.1 \\
\hline Agriculture & 24 & 8.1 \\
\hline Trade & 16 & 8.6 \\
\hline Tourism and hotel & 17 & 61.6 \\
\hline Government employee & 122 & 9.6 \\
\hline
\end{tabular}

Source: Field Survey, 2021

Table 4: Practices of Cultural Heritage Conservation

\begin{tabular}{|c|c|c|c|c|c|c|c|c|c|c|c|}
\hline \multirow{3}{*}{$\begin{array}{l}\text { Practices of Cultural Heritage } \\
\text { conservation measurement items }\end{array}$} & \multicolumn{10}{|c|}{ Respondents' Level of agreement } & \multirow{3}{*}{$\begin{array}{l}\text { Std. } \\
\text { Dev. }\end{array}$} \\
\hline & \multicolumn{2}{|c|}{$\begin{array}{l}\text { Strongly } \\
\text { Disagree }\end{array}$} & \multicolumn{2}{|c|}{ Disagree } & \multicolumn{2}{|c|}{ Undecided } & \multicolumn{2}{|l|}{ Agree } & \multicolumn{2}{|l|}{ Mean } & \\
\hline & Freq. & $\%$ & Freq. & $\%$ & Freq. & $\%$ & Freq. & $\%$ & Freq. & $\%$ & \\
\hline $\begin{array}{l}\text { There is an attempt at cultural heritage } \\
\text { conservation in your area }\end{array}$ & 24 & 12.1 & 61 & 30.8 & 31 & 15.7 & 67 & 33.8 & 15 & 7.6 & $\begin{array}{l}2.94 \\
1.199\end{array}$ \\
\hline $\begin{array}{l}\text { The local community have a sense of } \\
\text { belongingness and identity to the cultural } \\
\text { heritage of your area }\end{array}$ & 21 & 10.6 & 53 & 26.8 & 42 & 21.2 & 68 & 34.3 & 14 & 7.1 & $\begin{array}{l}3.01 ; \\
1.151\end{array}$ \\
\hline $\begin{array}{l}\text { The conservation activities conducted in } \\
\text { cultural heritages of your area is based } \\
\text { on research }\end{array}$ & 32 & 16.2 & 76 & 38.4 & 45 & 22.7 & 36 & 18.2 & 9 & 4.5 & $\begin{array}{l}2.57 \\
1.101\end{array}$ \\
\hline $\begin{array}{l}\text { Conservations are undertaken with due } \\
\text { consideration of the originality of } \\
\text { buildings }\end{array}$ & 20 & 10.1 & 59 & 29.8 & 45 & 22.7 & 60 & 30.3 & 14 & 7.1 & $\begin{array}{l}2.94 \\
1.136\end{array}$ \\
\hline $\begin{array}{l}\text { Follow up of heritages' existing situation } \\
\text { status for conservation is made regularly }\end{array}$ & 41 & 20.7 & 75 & 37.9 & 30 & 15.2 & 44 & 22.2 & 8 & 4.0 & $\begin{array}{l}2.51 \\
1.165\end{array}$ \\
\hline $\begin{array}{l}\text { Capacity building training on heritage } \\
\text { conservation are delivered at different } \\
\text { times }\end{array}$ & 52 & 26.3 & 78 & 39.4 & 33 & 16.7 & 16 & 8.1 & 19 & 9.6 & $\begin{array}{l}2.35 \\
1.224\end{array}$ \\
\hline
\end{tabular}

Source: Field Survey, 2021

Table 5: Kaiser-Meyer-Olkin Measure of Sampling Adequacy 


\begin{tabular}{|lll|}
\hline KMO and Bartlett's Test & & \\
\hline Kaiser-Meyer-Olkin Measure of Sampling Adequacy. & .768 \\
\hline Bartlett's Test of Sphericity & Approx. Chi-Square & 1019.124 \\
\cline { 2 - 3 } & df & 231 \\
\cline { 2 - 2 } & Sig. & .000 \\
\hline
\end{tabular}

Source: Survey, 2021

Table 6: Factor Extraction \& Total Variance Explained

\begin{tabular}{|c|c|c|c|c|c|c|c|c|c|}
\hline \multirow[t]{2}{*}{ Component } & \multicolumn{3}{|c|}{ Initial Eigenvalues } & \multicolumn{3}{|c|}{$\begin{array}{l}\text { Extraction Sums of Squared } \\
\text { Loadings }\end{array}$} & \multicolumn{3}{|c|}{$\begin{array}{l}\text { Rotation Sums of Squared } \\
\text { Loadings }\end{array}$} \\
\hline & Total & $\begin{array}{l}\% \text { of } \\
\text { Variance }\end{array}$ & $\begin{array}{l}\text { Cumulative } \\
\%\end{array}$ & Total & $\begin{array}{l}\% \text { of } \\
\text { Variance }\end{array}$ & $\begin{array}{l}\text { Cumulative } \\
\%\end{array}$ & Total & $\begin{array}{l}\% \text { of } \\
\text { Variance }\end{array}$ & $\begin{array}{l}\text { Cumulative } \\
\%\end{array}$ \\
\hline 1 & 4.742 & 21.554 & 21.554 & 4.742 & 21.554 & 21.554 & 3.240 & 14.726 & 14.726 \\
\hline 2 & 2.028 & 9.217 & 30.771 & 2.028 & 9.217 & 30.771 & 2.071 & 9.412 & 24.138 \\
\hline 3 & 1.597 & 7.257 & 38.028 & 1.597 & 7.257 & 38.028 & 1.938 & 8.808 & 32.945 \\
\hline 4 & 1.389 & 6.313 & 44.341 & 1.389 & 6.313 & 44.341 & 1.651 & 7.503 & 40.448 \\
\hline 5 & 1.239 & 5.633 & 49.973 & 1.239 & 5.633 & 49.973 & 1.590 & 7.228 & 47.677 \\
\hline 6 & 1.095 & 4.976 & 54.949 & 1.095 & 4.976 & 54.949 & 1.432 & 6.509 & 54.186 \\
\hline 7 & 1.003 & 4.561 & 59.511 & 1.003 & 4.561 & 59.511 & 1.172 & 5.325 & 59.511 \\
\hline 8 & .993 & 4.515 & 64.026 & & & & & & \\
\hline 9 & .881 & 4.006 & 68.032 & & & & & & \\
\hline 10 & .832 & 3.783 & 71.815 & & & & & & \\
\hline 11 & .772 & 3.509 & 75.324 & & & & & & \\
\hline 12 & .712 & 3.235 & 78.559 & & & & & & \\
\hline 13 & .663 & 3.015 & 81.574 & & & & & & \\
\hline 14 & .622 & 2.829 & 84.403 & & & & & & \\
\hline 15 & .562 & 2.555 & 86.957 & & & & & & \\
\hline 16 & .536 & 2.435 & 89.392 & & & & & & \\
\hline 17 & .488 & 2.216 & 91.609 & & & & & & \\
\hline 18 & .468 & 2.125 & 93.734 & & & & & & \\
\hline 19 & .389 & 1.767 & 95.500 & & & & & & \\
\hline 20 & .369 & 1.679 & 97.179 & & & & & & \\
\hline 21 & .330 & 1.501 & 98.680 & & & & & & \\
\hline 22 & .290 & 1.320 & 100.000 & & & & & & \\
\hline
\end{tabular}

Source: Field Survey, 2021

Table 8: Rotated Component Matrix and Component Loadings for Rotated loadings of Factors $(\mathrm{N}=198)$

Page $17 / 22$ 
Items

Component loadings

Commonality

$\begin{array}{lllllll}1 & 2 & 3 & 4 & 5 & 6 & 7\end{array}$

There is no regular monitoring and evaluation of cultural heritage status by the concerned body in

.671

your area

The growth of vegetation over the heritages is the $\quad .668$

challenges of heritages

Funding agencies lack the willingness to provide aids and loans to cultural heritages

.664

.570

The heritages are challenged by biological

.626

.418

.587

factors such as rats \& other biological organisms

Medias failed to expose the problems of

.571

.423

.564

heritages to the community in time

The heritage hosts more than its carrying

.571

.598

capacity during different events

Travel agents and tour operators are negligent to the sustainability of heritage

Population growth \& settlement programs have

impacts on the cultural heritage of the area

.485

There is a conflict of interest among stakeholders

to safeguard the cultural heritage

There is a practices of heritages conservation without the involvement of professional

.742

.621

.710

.611

.576

Little concern of government and local

authorities about the heritage in your area

Professionals lack enough commitment to engage in conservation practices

The local community are not concerned about

the cultural heritage of your area

The cultural heritage of the area are not

promoted for sustainable tourism development

There is the practice of illicit trafficking of cultural objects

There is a lack of buffer zone demarcations of the heritage sites

There are inappropriate conservation practices of cultural heritage

.811

.735

.773

.704

.724

660

.518

There is the practice of farming in and around the cultural heritages in your locality

Natural catastrophes and climate variations (flooding, frost, acidic rain, storm, heat from the sun) deteriorate cultural heritages

The local community have no positive attitude towards cultural heritages

\begin{tabular}{lllllllll} 
Eigenvalues & 4.742 & 2.028 & 1.597 & 1.389 & 1.239 & 1.095 & 1.003 \\
\hline \% of Variance & 14.726 & 9.412 & 8.808 & 7.503 & 7.222 & 6.509 & 5.325
\end{tabular}

Source: Filed Survey, 2021

Table 9: Correlation of potential challenges of Cultural Heritage Conservation 


\begin{tabular}{|c|c|c|c|c|c|c|c|c|c|c|}
\hline \multicolumn{11}{|c|}{ Correlations [r (sig. value at .05)] } \\
\hline & & & DV & 01 & 02 & 03 & 04 & 05 & 06 & 07 \\
\hline \multirow[t]{8}{*}{$\begin{array}{l}\text { Pearson } \\
r\end{array}$} & DV & $\begin{array}{l}\text { Practices of } \\
\text { Cultural } \\
\text { Heritage } \\
\text { Conservations }\end{array}$ & 1.000 & & & & & & & \\
\hline & 01 & $\begin{array}{l}\text { Lack of } \\
\text { proper } \\
\text { management, } \\
\text { monitoring } \\
\text { and } \\
\text { evaluation }\end{array}$ & $\begin{array}{l}-.154 \\
(.015)\end{array}$ & 1.000 & & & & & & \\
\hline & 02 & $\begin{array}{l}\text { Lack of } \\
\text { stakeholder } \\
\text { involvement } \\
\text { and } \\
\text { population } \\
\text { settlement }\end{array}$ & $\begin{array}{l}.057 \\
(.212)\end{array}$ & $.244(.000)$ & 1.000 & & & & & \\
\hline & 03 & $\begin{array}{l}\text { Lack of } \\
\text { government } \\
\text { concern and } \\
\text { professional } \\
\text { commitment }\end{array}$ & $\begin{array}{l}-.118 \\
(.049)\end{array}$ & $.470(.000)$ & $\begin{array}{l}.252 \\
(.000)\end{array}$ & 1.000 & & & & \\
\hline & 04 & $\begin{array}{l}\text { Lack of } \\
\text { community } \\
\text { concern, illicit } \\
\text { trafficking \& } \\
\text { promotion } \\
\text { towards } \\
\text { sustainable } \\
\text { development }\end{array}$ & $\begin{array}{l}-.229 \\
(.001)\end{array}$ & $.378(.000)$ & $\begin{array}{l}.389 \\
(.000)\end{array}$ & $.206(.002)$ & 1.000 & & & \\
\hline & 05 & $\begin{array}{l}\text { Poor } \\
\text { destination } \\
\text { management } \\
\text { and } \\
\text { conservation } \\
\text { practice }\end{array}$ & $\begin{array}{l}-.008 \\
(.458)\end{array}$ & $.095(.091)$ & $.089(.107)$ & $.087(.111)$ & $.088(.109)$ & 1.000 & & \\
\hline & 06 & $\begin{array}{l}\text { Natural } \\
\text { catastrophes } \\
\text { and } \\
\text { agricultural } \\
\text { practices }\end{array}$ & $\begin{array}{l}-.205 \\
(.002)\end{array}$ & $.318(.091)$ & $.193(.003)$ & $.236(.000)$ & $.228(.001)$ & $\begin{array}{l}-.048 \\
(.253)\end{array}$ & 1.000 & \\
\hline & 07 & $\begin{array}{l}\text { the local } \\
\text { community } \\
\text { have no } \\
\text { positive } \\
\text { attitude } \\
\text { towards } \\
\text { cultural } \\
\text { heritages }\end{array}$ & $\begin{array}{l}.016 \\
(.410)\end{array}$ & $-.001(.495)$ & $\begin{array}{l}.277( \\
.000)\end{array}$ & $.031(.334)$ & $.100(.080)$ & $.180(.006)$ & $\begin{array}{l}-.039 \\
(.292)\end{array}$ & 1.000 \\
\hline
\end{tabular}

Source: Field Survey, 2021

Table 10: ANOVA table model of the goodness of fit 


\begin{tabular}{|c|c|c|c|c|c|c|}
\hline \multicolumn{7}{|c|}{ ANOVA $^{a}$} \\
\hline \multicolumn{2}{|c|}{ Model } & Sum of Squares & df & Mean Square & $\mathrm{F}$ & Sig. \\
\hline \multirow[t]{3}{*}{1} & Regression & 13.363 & 7 & 1.909 & 3.525 & $.001^{\mathrm{b}}$ \\
\hline & Residual & 102.886 & 190 & .542 & & \\
\hline & Total & 116.249 & 197 & & & \\
\hline \multicolumn{7}{|c|}{ a. Dependent Variable: Practices of Cultural Heritage Conservations } \\
\hline \multicolumn{7}{|c|}{$\begin{array}{l}\text { b. Predictors: (Constant), The local community have no positive attitude towards cultural heritages, lack proper management, } \\
\text { monitoring and evaluation, poor destination management and conservation practice, natural catastrophes and agricultural } \\
\text { practices, lack of stakeholder involvement and population settlement, lack of community concern, illicit trafficking and promotion } \\
\text { towards sustainable development, lack of government concern and professional commitment }\end{array}$} \\
\hline
\end{tabular}

Source: Field Survey, 2021

Table 11: Model Summary Table: Practices of Cultural Heritage Conservation

\begin{tabular}{|c|c|c|c|c|c|}
\hline \multicolumn{6}{|c|}{ Model Summary ${ }^{b}$} \\
\hline Model & $\mathrm{R}$ & R Square & Adjusted R Square & Std. Error of the Estimate & Durbin-Watson \\
\hline 1 & $.281^{\mathrm{a}}$ & .079 & .060 & .745 & 1.821 \\
\hline \multicolumn{6}{|c|}{$\begin{array}{l}\text { a. Predictors: (Constant), natural catastrophes and agricultural practices, lack of community concern, illicit trafficking and } \\
\text { promotion towards sustainable development, lack of government concern and professional commitment, lack proper } \\
\text { management, monitoring and evaluation }\end{array}$} \\
\hline
\end{tabular}

Source: Field Survey, 2021

Table 12: Coefficients of Determination: Cultural Heritage Conservation Practice

\begin{tabular}{|c|c|c|c|c|c|c|c|c|}
\hline \multicolumn{2}{|c|}{ Model } & \multicolumn{2}{|c|}{$\begin{array}{l}\text { Unstandardized } \\
\text { Coefficients }\end{array}$} & \multirow{2}{*}{$\begin{array}{l}\text { Standardized } \\
\text { Coefficients } \\
\text { Beta }\end{array}$} & \multirow[t]{2}{*}{$\mathrm{t}$} & \multirow[t]{2}{*}{ Sig. } & \multicolumn{2}{|l|}{$\begin{array}{l}\text { Collinearity } \\
\text { Statistics }\end{array}$} \\
\hline & & B & $\begin{array}{l}\text { Std. } \\
\text { Error }\end{array}$ & & & & Tolerance & VIF \\
\hline \multirow[t]{8}{*}{1} & (Constant) & 3.498 & .338 & & 10.360 & .000 & & \\
\hline & $\begin{array}{l}\text { lack of proper management, monitoring and } \\
\text { evaluation }\end{array}$ & -.027 & .079 & -.029 & -.348 & .728 & .666 & 1.502 \\
\hline & $\begin{array}{l}\text { Lack of stakeholder involvement \& } \\
\text { population settlement }\end{array}$ & .179 & .065 & .216 & 2.745 & .007 & .753 & 1.328 \\
\hline & $\begin{array}{l}\text { lack of government concern and } \\
\text { professional commitment }\end{array}$ & -.046 & .054 & -.067 & -.856 & .393 & .751 & 1.331 \\
\hline & $\begin{array}{l}\text { lack of community concern, illicit trafficking } \\
\& \text { promotion towards sustainable } \\
\text { development }\end{array}$ & -.213 & .068 & -.248 & -3.154 & .002 & .755 & 1.324 \\
\hline & $\begin{array}{l}\text { Poor destination management and } \\
\text { conservation practice }\end{array}$ & $\begin{array}{l}1.477 \mathrm{E}- \\
5\end{array}$ & .068 & .000 & .000 & 1.000 & .948 & 1.055 \\
\hline & $\begin{array}{l}\text { Natural catastrophes and agricultural } \\
\text { practices }\end{array}$ & -.132 & .059 & -.166 & -2.249 & .026 & .859 & 1.164 \\
\hline & $\begin{array}{l}\text { The local community have no positive } \\
\text { attitude towards cultural heritages }\end{array}$ & -.014 & .044 & -.023 & -.317 & .751 & .888 & 1.126 \\
\hline
\end{tabular}




\section{Figures}

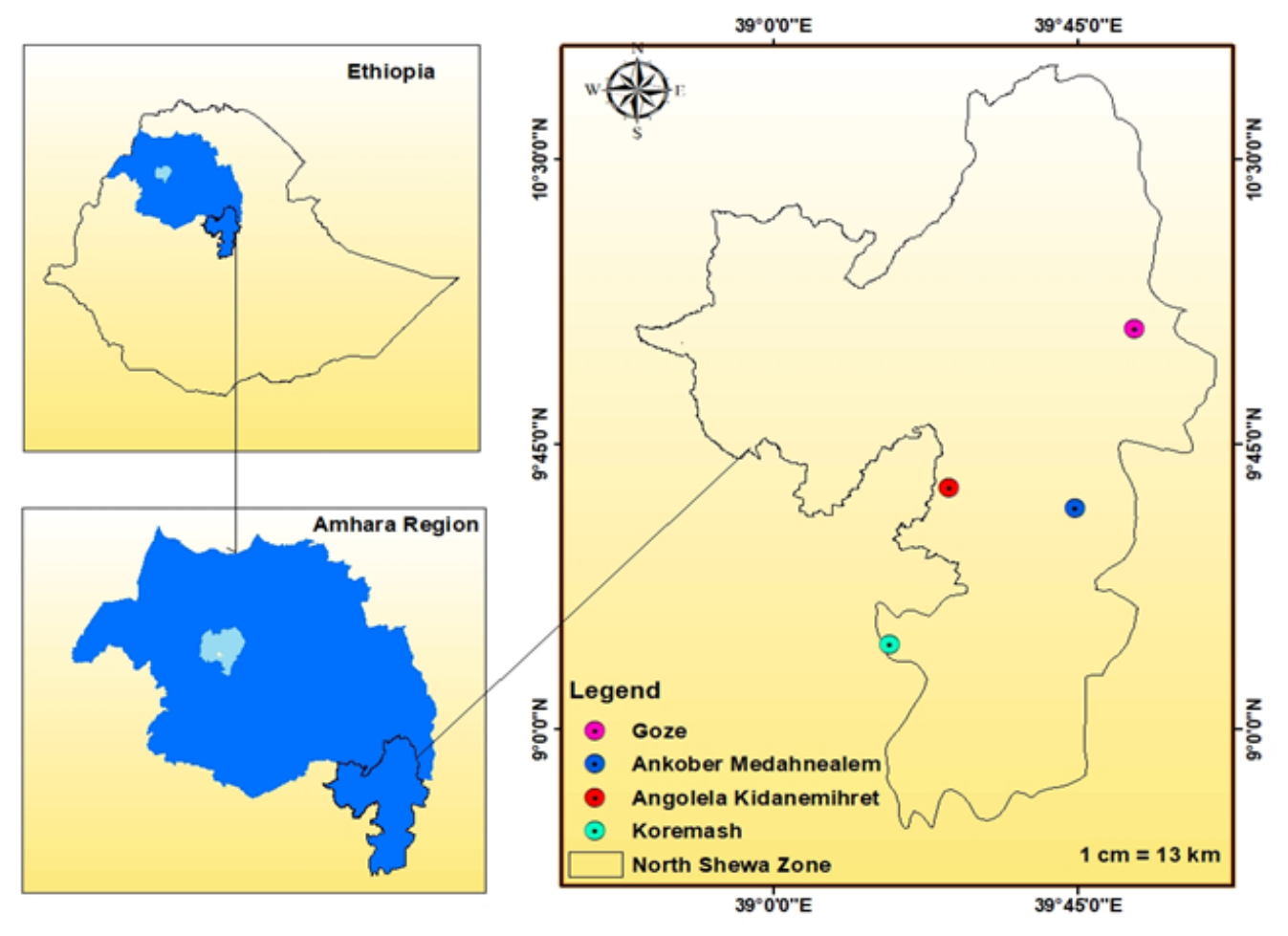

Figure 1

Map of the Study Area (Survey, 2021)

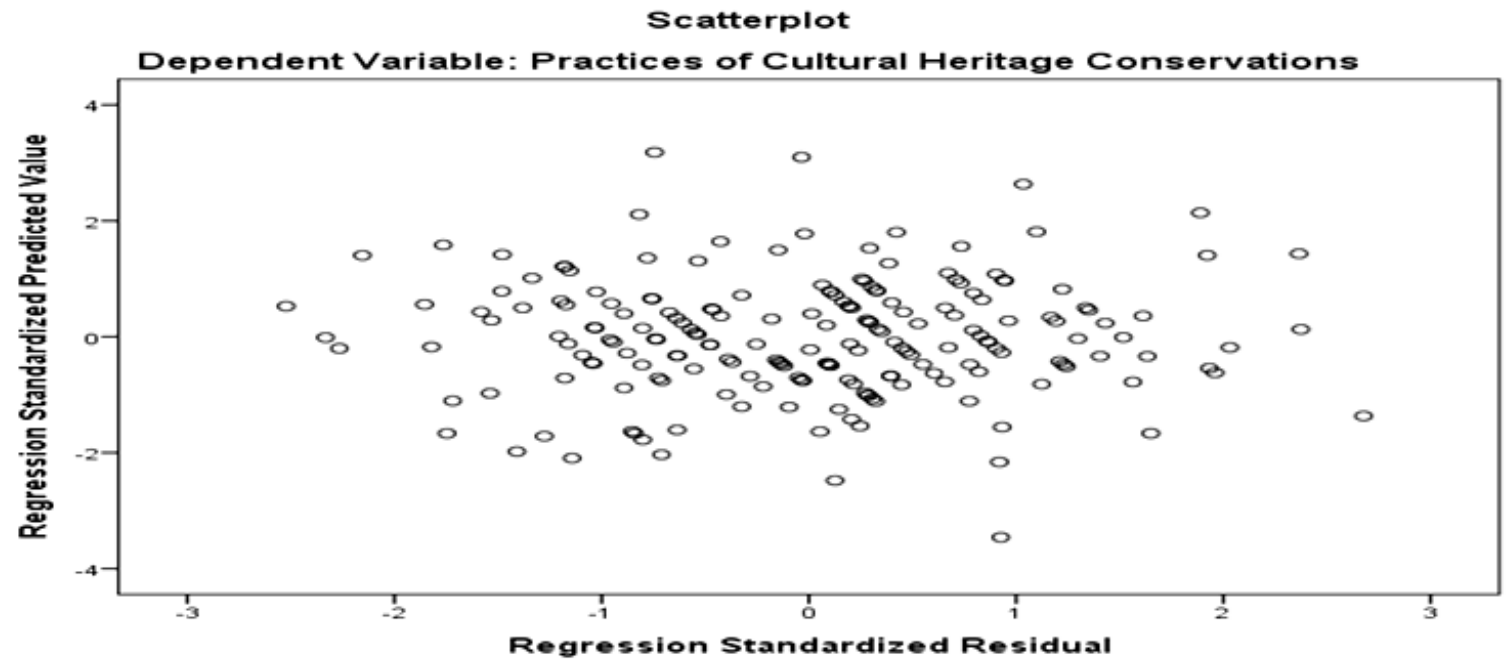

Figure 2 


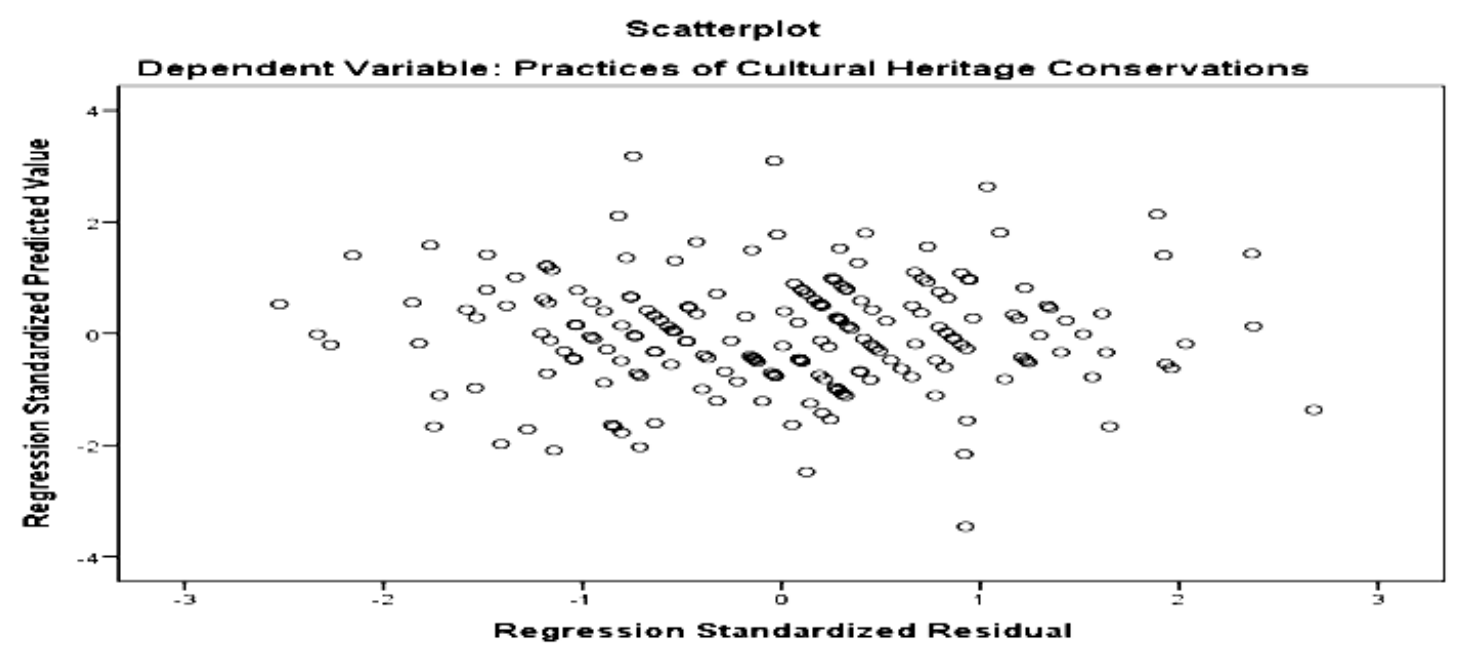

Figure 3

Scatter Plot; Conservation of Religious Heritage (Field Survey, 2021)

Normal P-P Plot of Regression Standardized Residual

Dependent Variable: Practices of Cultural Heritage Conservations

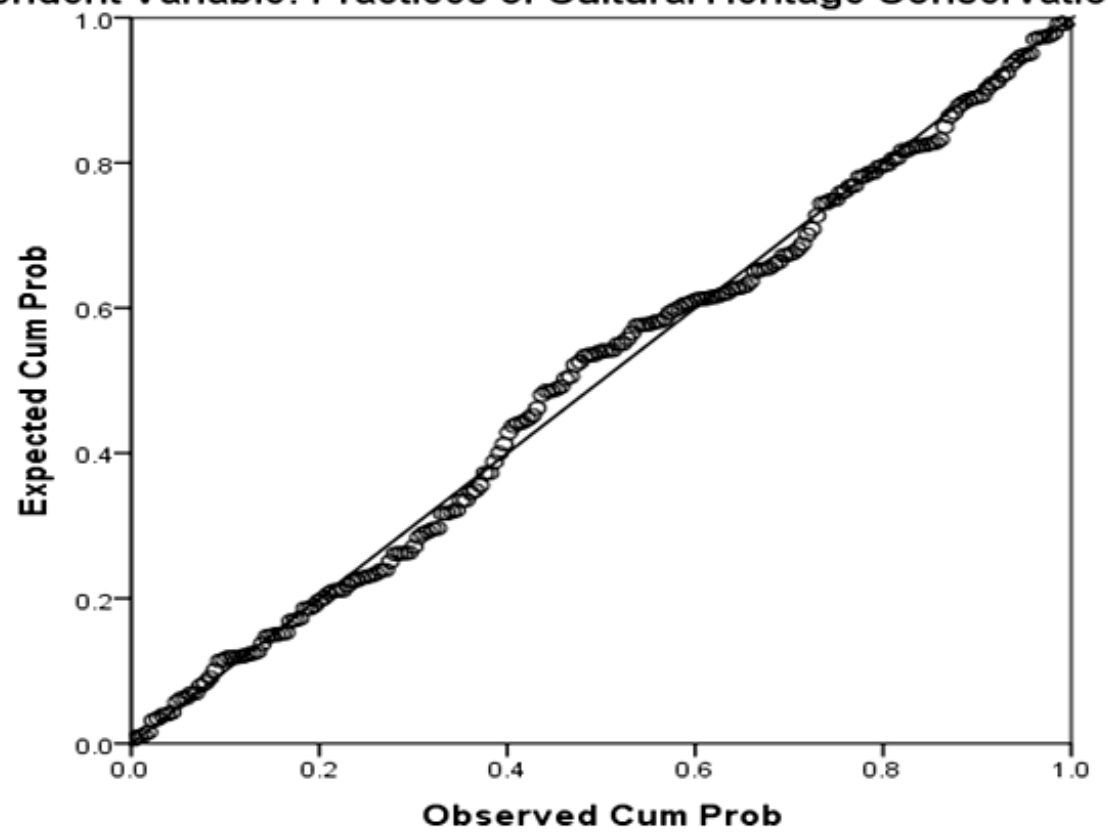

Figure 4

Normal P-P Plot of Dependent Variable (Field Survey, 2021) 